\title{
Alkaline Activation of Basic Oxygen Furnace Slag Modified Gold Mine Tailings for Building Material
}

\author{
Tebogo Mashifana $\left(\mathbb{D}\right.$, Jessica Sebothoma ${ }^{(D)}$, and Thandiwe Sithole \\ University of Johannesburg, Department of Chemical Engineering, P.O. Box 17011, Doornfontein 2088, South Africa \\ Correspondence should be addressed to Tebogo Mashifana; tmashifana@uj.ac.za
}

Received 10 March 2021; Revised 24 April 2021; Accepted 3 May 2021; Published 15 May 2021

Academic Editor: $\mathrm{Yu} \mathrm{Wu}$

Copyright (C 2021 Tebogo Mashifana et al. This is an open access article distributed under the Creative Commons Attribution License, which permits unrestricted use, distribution, and reproduction in any medium, provided the original work is properly cited.

\begin{abstract}
The mining industry generates large quantities of waste as tailings. The tailings have an adverse environmental impact. This study explored the utilization and stabilization of Barberton gold mine tailings (GMTs) and basic oxygen furnace slag (BOFS) to synthesize geopolymers for other applications. The geochemical, chemical, and geotechnical properties of GMT, BOFS, GMT geopolymer, and GMT: BOFS geopolymer were also studied. Sodium hydroxide $(\mathrm{NaOH})$ and potassium hydroxide $(\mathrm{KOH})$ were used as alkaline activators. The highest unconfined compressive strength (UCS) recorded for GMT geopolymers cured for 5 days at the elevated temperature of $90^{\circ} \mathrm{C}$ was $4.31 \mathrm{MPa}$ and $6.59 \mathrm{MPa}$ for $\mathrm{NaOH}$ and $\mathrm{KOH}$, respectively. GMT: BOFS geopolymer attained the UCS of $20.0 \mathrm{MPa}$ and $25.7 \mathrm{MPa}$, with $\mathrm{NaOH}$ and $\mathrm{KOH}$, respectively, at the same curing conditions. Characterization of the binders showed that BOFS was a good source of calcium, which had a positive effect on the geopolymer gels by balancing the ionic charges. The developed GMT: BOFS geopolymers satisfied the minimum requirements for nonfacing building masonry as stipulated by the ASTM C34-17a, ASTM C129-14c 0076a, and the SANS 227: 2007 for burnt clay masonry units and can be used as a mine backfill paste and for lightweight civil applications. The geopolymers passed the toxicity characteristic leaching procedure (TCLP), and the results yielded low heavy metals concentration, indicating that the geopolymers will not leach to the environment.
\end{abstract}

\section{Introduction}

Mine tailings are the major wastes generated by the mining industry. This waste is commonly landfilled as mine dumps. The major challenge with landfilling is the environment due to water and soil contamination and air pollution. Some of the tailings laden with that when discharged into water streams contaminate the water and affect aquatic life and animals. Many mine tailings contain heavy metals that have the potential to leach to the environment and pollute surface water [1]. In South Africa, there are more than 500 gold mine tailings (GMTs) occupying the land, with adverse effects on the environment. Three methods have been reported as solutions to reduce the environmental impacts posed by mine tailings: (1) isolation of mine, (2) chemical stabilization of mine tailings, and (3) a combination of these two methods $[2,3]$. The isolation of tailings entails techniques such as tailings capping the confinement of the tailings by constructing a system with a closure similar to that of landfills [4]. In the chemical stabilization process, the heavy metals are mobilized by introducing cementitious materials or chemicals into mine tailings [1]. This process can be conducted through chemical reactions and/or physical encapsulation [1]. In the past two decades, the common practice for the stabilization of mine tailings was through the utilization of pozzolanic materials such as lime and cement [5-11]. Other researchers have studied using wastes such as aluminum, fly ash, and slag as stabilizers [12, 13]. With the development of numerous technologies, geopolymerization or alkaline activation has been reported to be the most promising environmentally friendly and economical technology to effectively stabilize mine tailings. This process also allows for the mine tailings to be used for other applications as cemented paste [14]. The first countries reported to have 
used cemented tailings paste as a filler are Australia, German, and North America [15]. Worldwide, more than 100 cemented paste backfill factories have been reported to be active [14]. The utilization of mine tailings as cemented paste reduced the tailings that must be built and managed on the land [16]. Moreover, the replacement of Portland cement with new innovative material would contribute greatly to the reduction of greenhouse gases, whereby waste is used instead of cement.

The process of geopolymerization entails the formation of gels on the surface of mine tailings whereby the gel binds the particles together [1]. A geopolymer is an amorphous binder, and its formation is favored by alkali activation of high $\mathrm{pH}$ materials containing silica and alumina and cured at room or slightly elevated temperature [17]. In the development of geopolymer, an amorphous or semiamorphous structure is formed by the activation of alumina silicate-containing material in an alkaline environment [18]. Geopolymers have high adsorption capacity and can immobilize contaminants such as heavy metals [19]; this, therefore, makes geopolymers to be a sustainable solution to effectively address the challenges associated with GMT. Kiventerä et al. [20] investigated the use of gold tailings as raw material in the development of geopolymers. The unconfined compressive strength obtained using only raw GMT was between 1.3 MPa and 3.5 MPa. With the alkaline activation of GMT and the addition of granulated blast furnace slag (GBFS), the strength attained was in the range of 1.8 $\mathrm{MPa}$ and $25 \mathrm{MPa}$, showing that alkaline activation significantly improved the strength of GMT geopolymers. The researchers also concluded that through alkaline activation, binders with sufficient strength for the material to be utilized in the construction industry are formed [20]. In the study conducted by Aseniero et al. [21], to utilize GMT as geopolymeric source material, the $\mathrm{Si} / \mathrm{Al}$ ratio of the tailings used samples was 4.81. The strength attained for the synthesized geopolymer bricks was 5.48 MPa [21]. An investigation on the alkaline activation of GMT as an option for inertization, conducted by Kiventerä et al. [20], showed that through geopolymerization, heavy metals such as $\mathrm{Cu}, \mathrm{Ni}, \mathrm{Cr}, \mathrm{Mn}$, and Zn were completely immobilized.

Basic oxygen furnace slag (BOFS) is a by-product of the steel manufacturing industry. The steel industry is amongst one of the largest waste producers. The global slag output from the steel industry was reported to be over 1600 million tons per annum [22]. In South Africa, the iron World Steel Association production statistics showed a generation of up to 37 million tons of blast furnace slag over a 12 year period [23]. Both GMT and BOFS contaminate the environment because of the pollutants in the material. It is therefore crucial that these two materials are beneficiated.

In the study to enhance the pozzolanic activity of granulated copper slag by adding calcium oxide $(\mathrm{CaO})$, Feng et al. [24] reported that with $20 \%$ of $\mathrm{CaO}$, the strength activity index for the mortar increased, which confirmed improvement in the modified slag. A geopolymer using lithium slag and sodium hydroxide $(\mathrm{NaOH})$ as an activator was synthesized by $\mathrm{He}$ et al. [25]. The binder developed was used to replace $30 \%$ of Portland pozzolana cement. The specimen with high $\mathrm{NaOH}$ showed the highest strength of 32.3 MPa and 39.7 MPa at 28- and 56-days curing, respectively. The results obtained were like the strength of PPC specimens of $33.4 \mathrm{MPa}$ and $41.8 \mathrm{MPa}$, for similar curing periods [25]. Granulated blast furnace slag was alkaline activated by $\mathrm{NaOH}$ and $\mathrm{KOH}$ to develop a building and construction material [26]. Phosphate mine tailings were alkaline activated using $\mathrm{NaOH}$, and slag was added to adjust the gel structure [27]. The results showed the optimum strength at the mix design of $60 \%$ tailings and $40 \%$ slag. With the increment of slag in the mix design, there was a formation of N-A-S-H and C-A-S-H gels [27]. Fly ash and ground granulated blast furnace slag were used to develop a geopolymer paste, using $\mathrm{NaOH}$ and sodium silicate $\left(\mathrm{Na}_{2} \mathrm{SiO}_{3}\right)$ as an activator [28]. The setting time of the paste decreased with the increase in $\mathrm{Na}_{2} \mathrm{SiO}_{3}$ concentration. The increment in $\mathrm{NaOH}$ molarity resulted in a decrease in setting time and consistency [28]. Jiao et al. [29] studied the effect of alkaline activator dosage on the properties of alkaline activated blast furnace slag using an activator consisting of $\mathrm{NaOH}$ and $\mathrm{Na}_{2} \mathrm{SiO}_{3}$. Compressive strength of $55 \mathrm{MPa}$ was obtained at 1-day curing, with a maximum strength of $102 \mathrm{MPa}$ [29].

Alkaline activation of gold tailings to develop a binder is not a new concept. Silicious gold tailings were converted to value-added products through alkaline activation using two mixtures containing calcium oxide, anhydride, and cement [30]. $\mathrm{NaOH}$ and $\mathrm{Na}_{2} \mathrm{SiO}_{3}$ were applied as new options for inertization of gold tailings, and the material was firstly activated hydrothermally at the temperature of $200^{\circ} \mathrm{C}$ [31]. Heavy metals and sulfates were immobilized in gold tailings using hydrated line and $\mathrm{NaOH} / \mathrm{Na}_{2} \mathrm{SiO}_{3}$ activators [32] Geopolymers were synthesized from alkaline activation of gold tailings using cement, $\mathrm{NaOH}$, and $\mathrm{Na}_{2} \mathrm{SiO}_{3}$ [33]. The tailings were pretreated at elevated temperatures above $500^{\circ} \mathrm{C}$ [33]. These are the recent developments in the activation of gold tailings, which shows that activators widely studied are alkaline activators with the addition of sodium silicate. Studies have reported sodium silicate as being one of the most expensive alkaline activators, with high environmental impact $[20,34]$. The other reported studies show the addition of cement in the mix design and pretreating gold tailings at elevated temperatures, which is energy intensive. The production of cement is one of the contributors to global warming through the emission of greenhouse gases. An estimated 4.8 billion tons of $\mathrm{CO}_{2}$ gas was emitted to the atmosphere by the cement industry in 2020 [35].

In this study, GMT was activated without the addition of a silica source, such as sodium silicate. The source of silicate was the GMT studied, as they consist of a high content of $\mathrm{SiO}_{2} / \mathrm{Al}_{2} \mathrm{O}_{3}$. To improve the properties of the geopolymers developed, BOFS was incorporated into the mix design. $\mathrm{NaOH}$ and potassium hydroxide $(\mathrm{KOH})$ were studied separately as alkaline activators, and a comparative study was conducted to determine the activator that yields the best results.

$\mathrm{NaOH}$ and $\mathrm{KOH}$ are the commonly used alkaline activators. The other activator that can be used in the geopolymerization process is calcium hydroxide $\mathrm{Ca}(\mathrm{OH})_{2}$. In 
the geopolymerization process, the $\mathrm{Na}^{+}$and $\mathrm{K}^{+}$from alkaline activators charge to balance the excess tetrahedrons negative charge, which is incorporated into the alumina silicate network. The charge balance using $\mathrm{Ca}^{2+}$ does yield the same results as the one charge remains in the system. It is worth noting that there are two processes to produce $\mathrm{Ca}(\mathrm{OH})^{2}$, which is through lime hydration or from the reaction of $\mathrm{NaOH}$ with sodium chloride. Using lime from the latter process will be costly as $\mathrm{NaOH}$ is already involved in the reaction. The main drive for the selected alkali activators is the reduction of carbon dioxide, which is emitted in the process of lime production.

The readily available GMT used in this study had an alumina silicate ratio of 4.75 ; this makes geopolymerization of tailings a sustainable solution to deal with GMT waste. The developed geopolymers were also evaluated for potential environmental impact. This study presents the holistic beneficiation of two materials, which contribute to environmental pollution and provide a novel solution for alternative cost-effective and environmentally friendly building materials.

\section{Materials and Methods}

2.1. Materials. The GMTs were collected from a mining company in Mpumalanga region of South Africa. GBFS was obtained from a steel manufacturing company. Before the experiments, baseline tests were conducted to study the geochemical and geotechnical properties of the material. Potassium hydroxide $(\mathrm{KOH})$ and sodium hydroxide $(\mathrm{NaOH})$ were used as alkaline activators.

2.2. Development of Geopolymers. To determine the optimum ratio for the development of GMT: BOFS geopolymers, maximum dry density (MDD) and optimum most content (OMC) for different mix designs of GMT: BOFS were determined. The mix design that yielded the highest MDD was then used for alkaline activations tests. Different concentrations of alkaline activators were investigated, and the specimens were cured at different temperatures to determine the optimum curing temperature, based on the UCS attained. The geopolymer with the optimum UCS was further studied. Figure 1 shows the procedure that was followed for the development of geopolymers. Alkali activator concentrations of $5 \mathrm{M}, 10 \mathrm{M}, 15 \mathrm{M}$, and $20 \mathrm{M}$ were investigated, and the one that yielded the best results was used for further tests. A liquid to solid ratio of 0.2 and curing temperature of $90^{\circ} \mathrm{C}$ for a duration of 5 days were the values fixed as the preliminary study, and it was based on the literature. The effect of liquid to solid ratio was studied by varying ratios between $0.15,0.2$, and 0.25 of an alkaline solution to dry raw material (tailings). For GMT: BOFS geopolymer, the ratios studied were $0.17,0.2$, and 0.23 as higher ratios provided unworkable pastes.

2.3. Characterization. The elemental composition of GMT, $\mathrm{BOFS}$, and geopolymers developed was studied by X-ray fluorescence (XRF; Rigaku ZSX PRIMUS). The samples were pulverized and mixed with Sasol wax. The mixture was pelletized and dried in an oven for 1 hour, at the temperature of $50^{\circ} \mathrm{C}$. After drying, the samples were placed in a spectrometer compartment. The spectrometer was equipped with a $4 \mathrm{~kW}$ Rh anode $\mathrm{X}$-ray tube end window and powered at a current of $60 \mathrm{~mA}$ and voltage of $40 \mathrm{kV}$, for heavy elements. The light elements were powered at a voltage of $30 \mathrm{kV}$ and a current of $100 \mathrm{~mA}$. X-ray diffraction (XRD; Rigaku Ultima IV) was used to study mineralogy. The X-ray diffractometer with $\mathrm{CuK} \alpha$ radiation with the voltage of $40 \mathrm{kV}$, current of $40 \mathrm{~mA}$, measuring time of $50 \mathrm{~s}$, scanning range between 4 and $100^{\circ} \mathrm{C}$, and $0.017^{\circ} 2 \theta$ step scan was applied.

The micrograph was studied by using the scanning electron microscope (SEM; Tescan Vega 3 XMU). Finely ground samples were carbon coated and mounted on the microscope.

The functional groups were detected by Fourier transform infrared spectroscopy (FTIR). Finely ground samples were placed on the FTIR spectrometer.

A Malvern particle size analyzer (Hydro 2000 LV) was used to measure the particle size distribution of raw materials and developed geopolymer [36]. The composites were subjected to toxic leaching characteristic procedure (TCLP) to study their leachability. The developed composites were milled to $80 \%-75 \mu \mathrm{m}$. A buffer solution containing sodium hydroxide and acetic acid at a $\mathrm{pH}$ of $4.93 \pm 0.05$ and a liquid to solid ratio of $20: 1$ was used to leach the material $[37,38]$. Leachates from TCLP tests were analyzed using atomic absorption apectroscopy (AAS).

\section{Results}

3.1. Elemental Analysis of GMT and GBFS. Table 1 shows the elemental composition of GMT and BOFS. GMT was predominated with silicon dioxide $\left(\mathrm{SiO}_{2}\right)$, aluminum oxide $\left(\mathrm{Al}_{2} \mathrm{O}_{3}\right)$, and iron oxide $\left(\mathrm{Fe}_{2} \mathrm{O}_{3}\right)$, with relative proportions of $57.9 \mathrm{wt} . \%, 12.2 \mathrm{wt} . \%$, and $10.4 \mathrm{wt} . \%$, respectively. The ratio of $\mathrm{SiO}_{2} / \mathrm{Al}_{2} \mathrm{O}_{3}$ is 4.75 . The ratio is similar to the GMT used by Aseniero et al. which was 4.81 and reported to be close to the recommended value for geopolymerization [21].

There were no radionuclides detected in GMT, indicating that the tailings were not radioactive. Calcium oxide $(\mathrm{CaO})$, $\mathrm{Fe}_{2} \mathrm{O}_{3}$, and $\mathrm{SiO}_{2}$ were the major constituents in BOFS, with the relative proportions of $46 \mathrm{wt} . \%, 29.6 \mathrm{wt} . \%$, and $10.2 \mathrm{wt} \%$, respectively. The composition of BOFS is close to the elemental composition of BOFS reported by Sithole et al. [39], whereby the predominant constituents in BOFS were $\mathrm{CaO}, \mathrm{Fe}_{2} \mathrm{O}_{3}$, and $\mathrm{SiO}_{2}$ with the relative proportion of $51.81 \mathrm{wt} . \%, 24.6 \mathrm{wt} . \%$, and 7.7 wt.\%, respectively. Similar results were obtained by Belhadj et al. [40], where three types of BOFS studied for activation were predominated with $\mathrm{CaO}, \mathrm{Fe}_{2} \mathrm{O}_{3}$, and $\mathrm{SiO}_{2}$.

$\mathrm{SiO}_{2} / \mathrm{Al}_{2} \mathrm{O}_{3}$ in $\mathrm{BOFS}$ was calculated to be 1.42 , which is less than that of GMT.

3.2. Mineralogical Analysis and FTIR of GMT and GBFS. The XRD and FTIR analysis of raw GMT and BOFS is presented in Figure 2. 


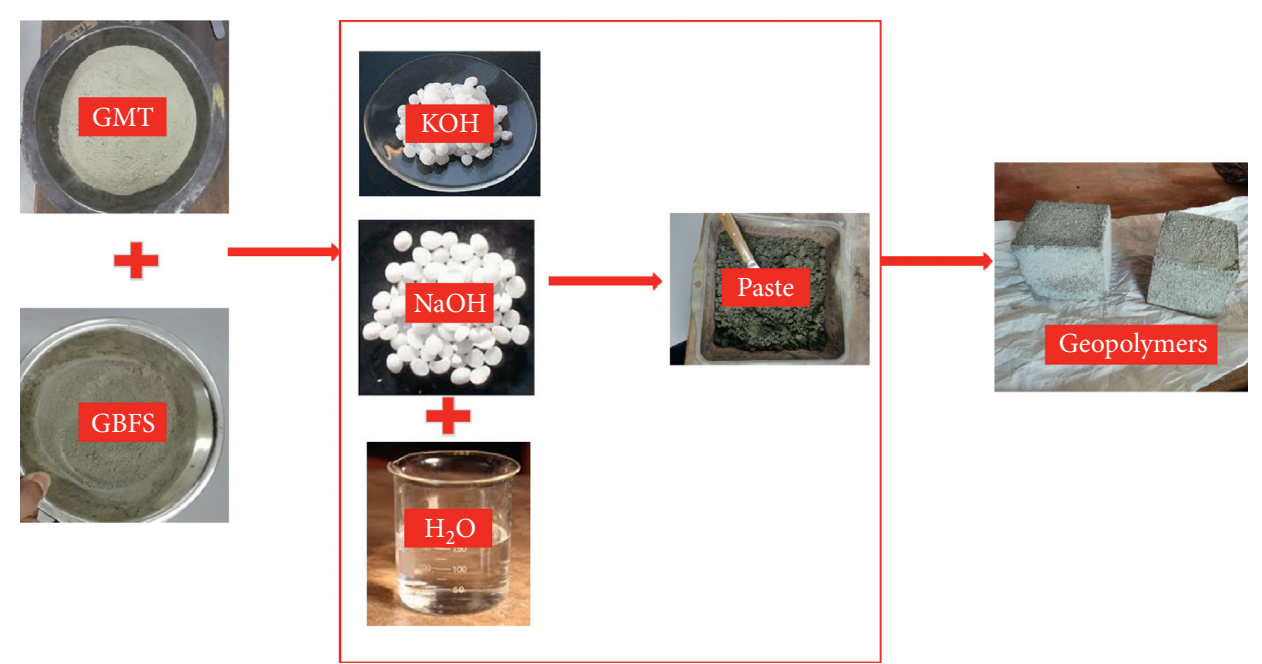

FIGURE 1: Experimental procedure flow chart for the development of the alkaline activated specimens.

TABLE 1: Elemental analysis of GMT and BOFS.

\begin{tabular}{lcc}
\hline Component (mass \%) & GMT & BOFS \\
\hline $\mathrm{SiO}_{2}$ & 57.9 & 10.2 \\
$\mathrm{Al}_{2} \mathrm{O}_{3}$ & 12.2 & 3.96 \\
$\mathrm{Fe}_{2} \mathrm{O}_{3}$ & 10.4 & 29.6 \\
$\mathrm{CaO}$ & 5.52 & 46.0 \\
$\mathrm{MgO}$ & 4.63 & 3.30 \\
$\mathrm{~K}_{2} \mathrm{O}$ & 4.14 & 0.069 \\
$\mathrm{SO}_{3}$ & 2.59 & 0.819 \\
$\mathrm{MnO}_{\mathrm{TiO}}$ & 0.243 & 4.23 \\
$\mathrm{As}_{2} \mathrm{O}_{3}$ & 0.705 & 0.337 \\
$\mathrm{Na}_{2} \mathrm{O}$ & 0.517 & - \\
$\mathrm{Cr}_{2} \mathrm{O}_{3}$ & 0.500 & 0.161 \\
$\mathrm{P}_{2} \mathrm{O}_{5}$ & 0.266 & 0.338 \\
$\mathrm{NiO}$ & 0.071 & 0.799 \\
$\mathrm{~V}_{2} \mathrm{O}_{5}$ & 0.061 & 0.015 \\
$\mathrm{ZrO}_{2}$ & 0.038 & 0.127 \\
$\mathrm{Rb}_{2} \mathrm{O}$ & 0.023 & 0.008 \\
$\mathrm{As}_{2} \mathrm{O}_{3}$ & 0.018 & - \\
$\mathrm{Cl}$ & 0.018 & - \\
$\mathrm{ZnO}_{\mathrm{CuO}}$ & 0.016 & - \\
$\mathrm{ZrO}_{2}$ & 0.015 & - \\
$\mathrm{Nb}_{2} \mathrm{O}_{5}$ & 0.013 & 0.009 \\
\hline
\end{tabular}

As detected in the elemental analysis of GMT, the highest peaks were measured at 2 theta 21 and 26, showing quartz $\left(\mathrm{SiO}_{2}\right)$ is the major crystalline phase. These results are similar to the mineralogy of GMT studied by [19]. There were also traces of gypsum in the phase composition of the GMT. Kiventerä et al. [20] analyzed gold mine tailings from Finland, and their findings were similar to these in that the phases identified include quartz, albite, and gypsum.

The XRD pattern of BOFS shows that the main mineral phases are calcium silicate (CAS), $\mathrm{CaO}$, with minor phases of periclase $(\mathrm{MgO})$ and $\mathrm{Fe}_{3} \mathrm{O}_{4}$. The presence of $\mathrm{Fe}_{3} \mathrm{O}_{4}$ in BOFS shows that the material is magnetic, and this leads to difficulty in crushing [40]. Calcium oxide silicate is a constituent normally present in, BOF slag [41], and it was also detected in the BOFS used in this study.

The main feature for GMT FTIR spectra is the central band at around $2400 \mathrm{~cm}^{-1}$. The band shifted to the lower wave number of about $1000 \mathrm{~cm}^{-1}$, similar to the GMT FTIR spectra reported by [19], which is attributed to Al-O-Si or Si$\mathrm{O}-\mathrm{Si}$. The main spectra in BOFS were at the wavenumber of about $1300 \mathrm{~cm}^{-1}$ and $800 \mathrm{~cm}^{-1}$. Although weak, the peak around $2300 \mathrm{~cm}^{-1}$ corresponds to $\mathrm{MgO}$ [42].

3.3. Micrography of GMT and BOFS. The micrography for GMT and BOFS is presented in Figure 3.

GMT micrography exhibits densely packed crystalline particles with irregular shapes. GMT also had smaller and larger particles, which are exhibited granular shaped [21]. The coating on the surface of the grain is associated with $\mathrm{Si}$, which was also detected in the elemental composition and mineralogy as quartz.

The micrography for BOFS showed that the material was nonspherical with glassy microstructures of irregular shapes. A rougher and cloudy texture surface was also evident, which can be attributed to $\mathrm{CaO}[43,44]$, an observation also reported by [45]. Ca was spread throughout the particles, and it was mainly detected on larger particles. The microstructures of GMT and BFS, before the geopolymerization process, showed loose particles, whose metrics were transformed to be compact and filled spaces due to the formation of geopolymer gel [26], after geopolymerization as presented in Figure 4.

3.4. Atterberg Limits and Specific Gravity of GMT and BOFS. Table 2 presents the liquid limit (LL), plastic limit (PL), and specific gravity (SG) of GMT and BOFS. Both GMT and BOFS are not plastic materials, with LL of 17 and 13, respectively. The tailings studied were also nonplastic [46]. Ahmed and Siddiqua [46] reported SG of 3.17 for GMT [28], a value slightly higher than what was measured for GMT in 


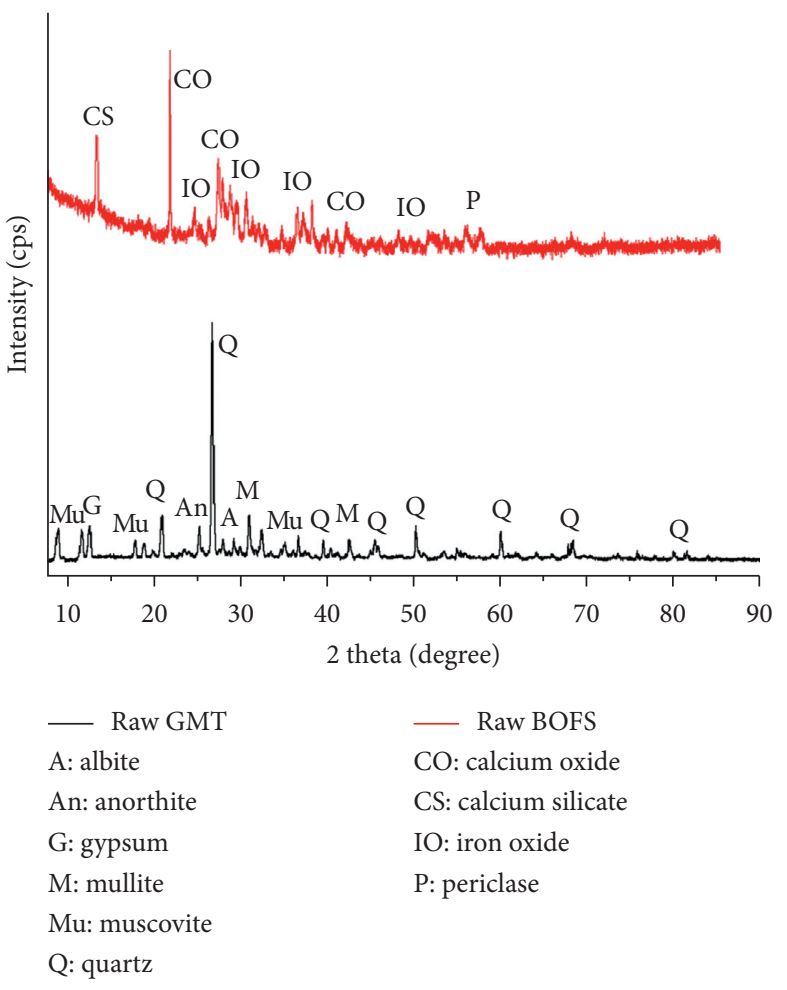

(a)

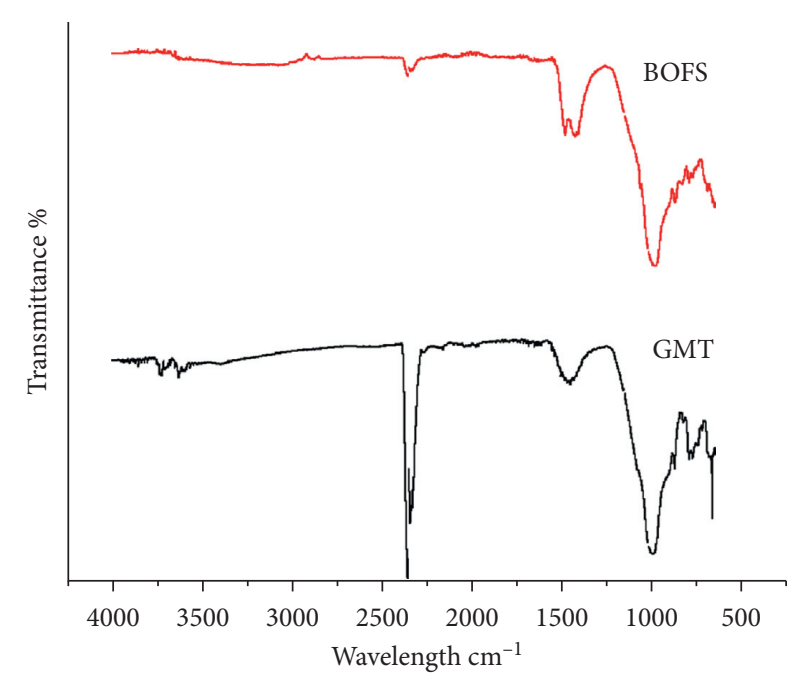

(b)

Figure 2: (a) Mineralogy of raw GMT and BOFS; (b) FTIR of raw GMT and BOFS.

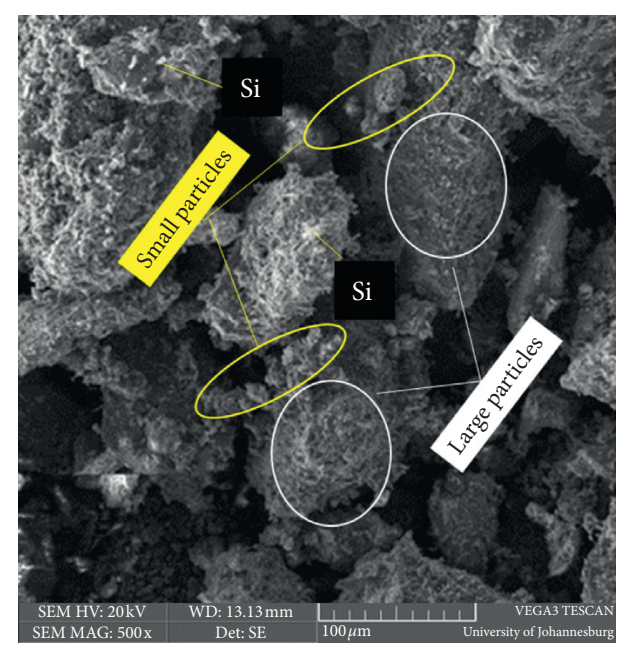

(a)

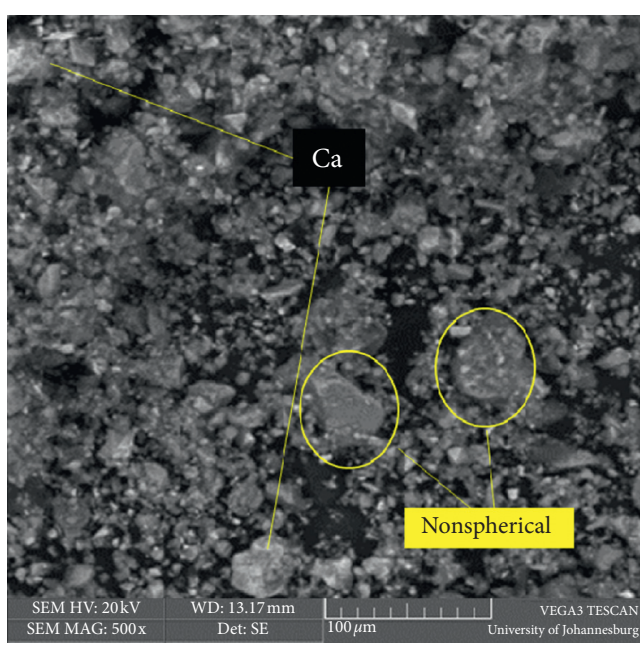

(b)

FIGURE 3: Micrography of (a) raw GMT and (b) BOFS.

this study. The SG for BOFS is similar to the SG observed by Kuo et al. [47], who reported a value of 3.31 .

\subsection{Geopolymerization of GMT and BOFS}

3.5.1. Maximum Dry Density (MDD) and Optimum Moisture Content (OMC) of GMT and BOFS. The MDD and OMC for GMT: BOFS were studied to determine the mix design that yields the optimum MDD. The results obtained are presented in Figure 5.

GMT had an MDD of $1740 \mathrm{~kg} / \mathrm{m}^{3}$ and OMC of 15.4. The mix design containing 50\% GMT and 50\% BOFS yielded the highest MDD. Reduction in GMT content in the mix design resulted in an increment in MDD to $2015 \mathrm{~kg} / \mathrm{m}^{3}$ and OMC of 13.66, in 50GMT:50BOFS specimens. The composition of 50GMT: 50 BOFS was then used for the development of geopolymers. 


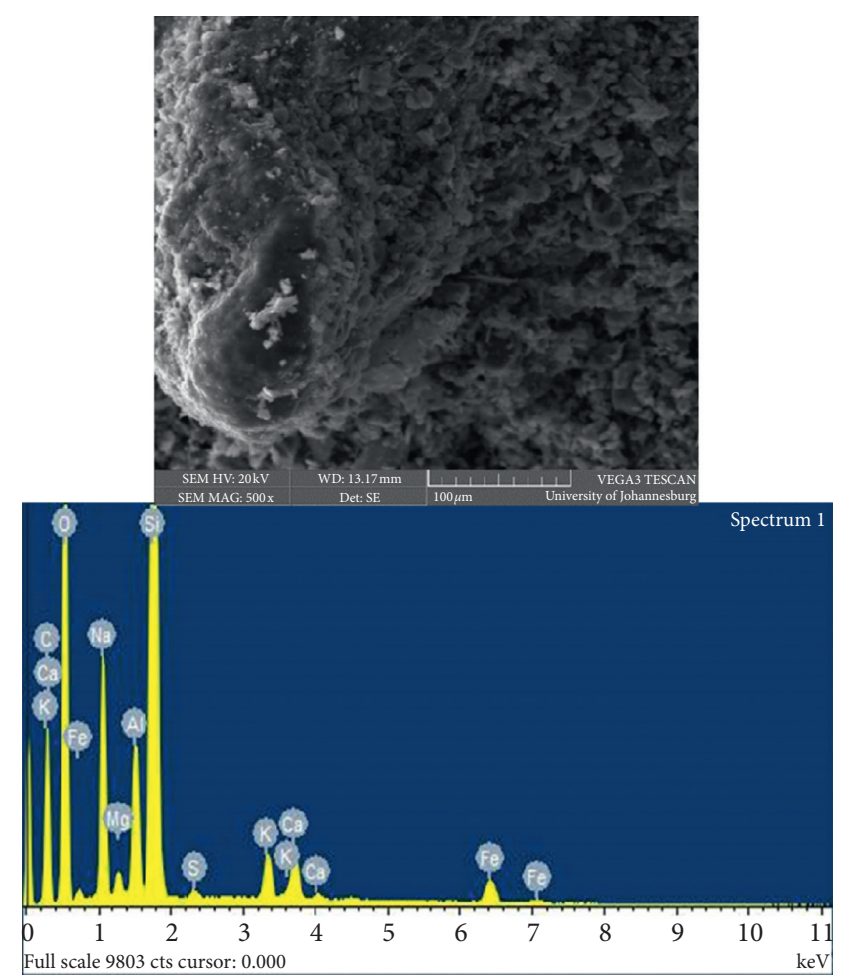

(a)

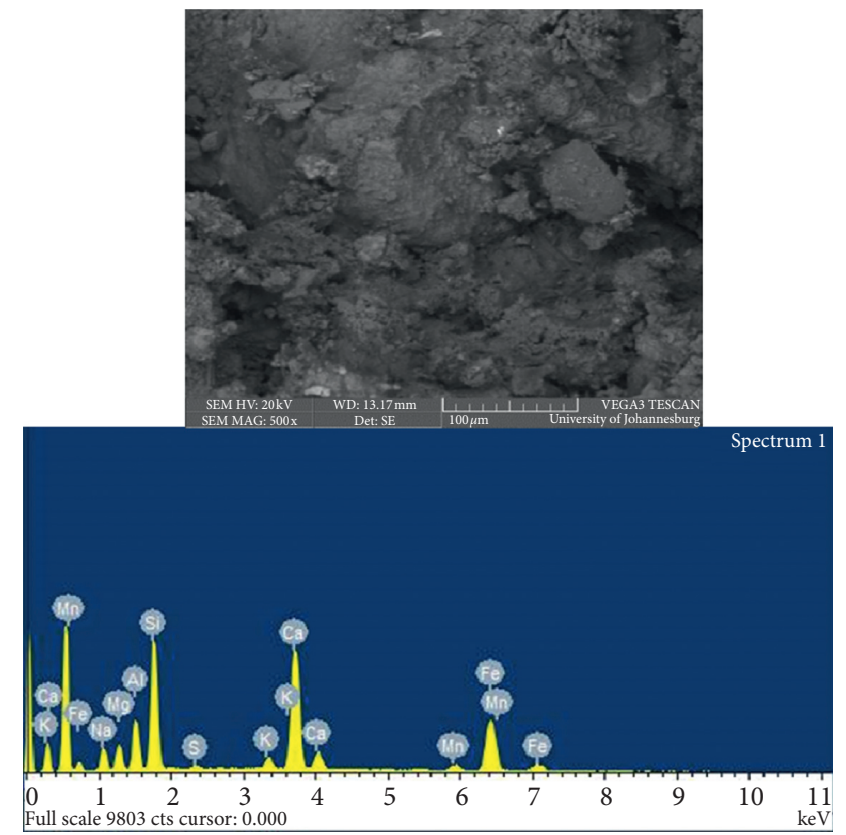

(c)

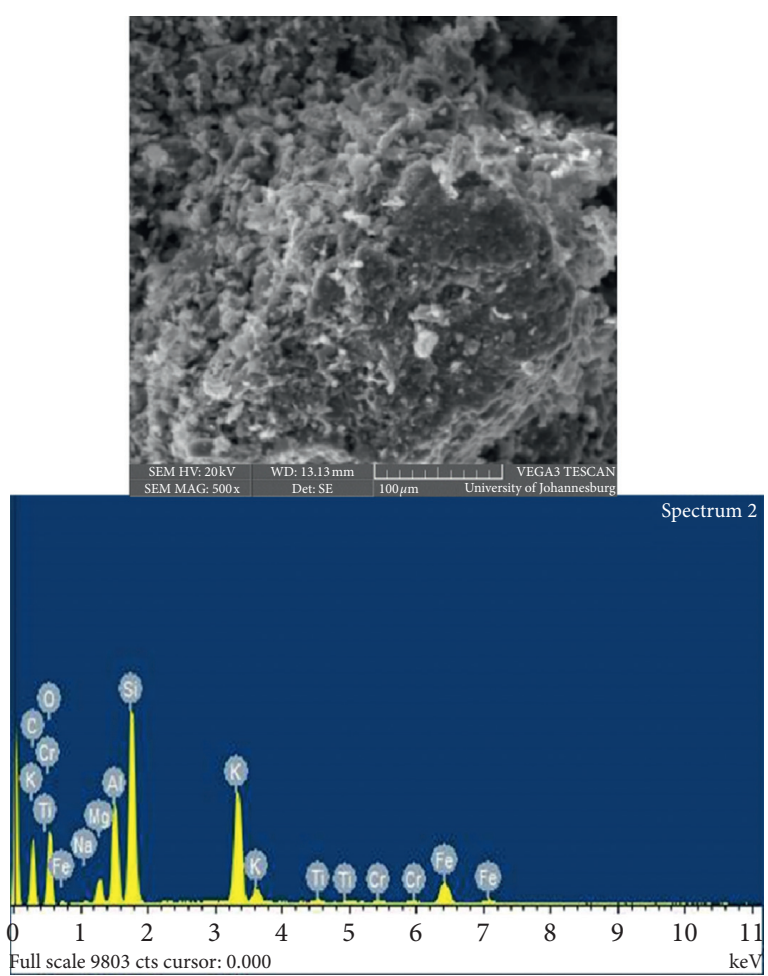

(b)

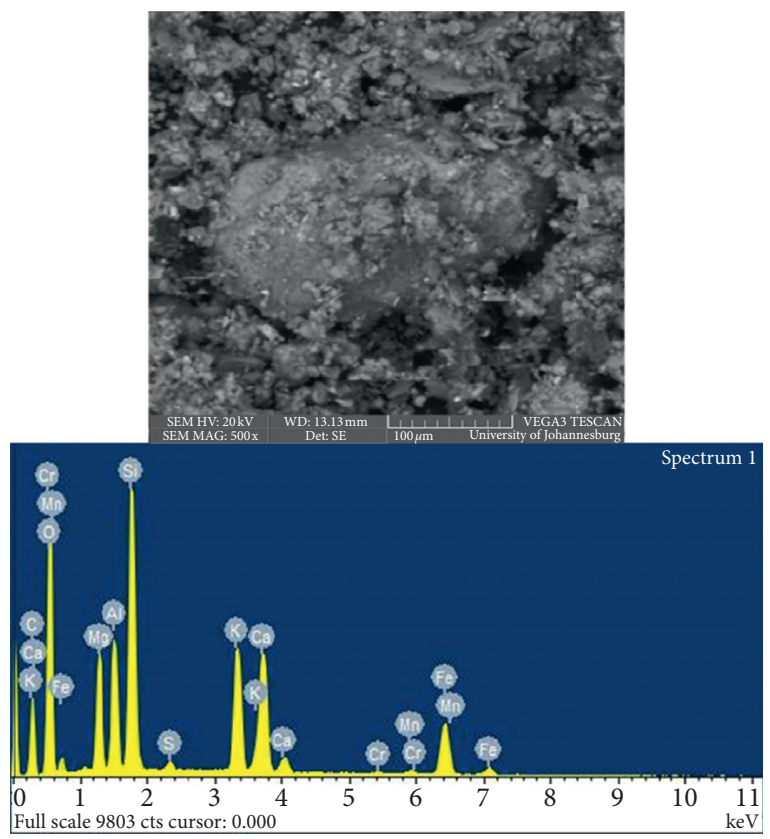

(d)

FIgURE 4: Micrograph and EDS of (a) GMT geopolymer at optimum conditions, $15 \mathrm{M} \mathrm{NaOH}$; (b) GMT geopolymer at optimum conditions, $10 \mathrm{M} \mathrm{KOH}$; (c) GMT: BOFS geopolymer at elevated conditions, $10 \mathrm{M} \mathrm{NaOH}$; (d) GMT: BOFS geopolymer at optimum conditions, $10 \mathrm{M} \mathrm{KOH}$.

3.5.2. Effect of the Concentration of Alkaline Activators on the UCS of Developed GMT and GMT: BOFS Geopolymers. The MDD and OMC for GMT: BOFS were studied to determine the mix design that yields the optimum MDD. To determine the activator that produces the optimum results, $\mathrm{NaOH}$ and $\mathrm{KOH}$ were used as activators. The concentrations of $5 \mathrm{M}, 10 \mathrm{M}, 15 \mathrm{M}$, and $20 \mathrm{M}$ for both activators were investigated. Figure 6 shows the UCS obtained when different activator concentrations were investigated for GMT and GMT: BOFS geopolymers. The developed geopolymers were cured at elevated temperatures of $60^{\circ} \mathrm{C}, 90^{\circ} \mathrm{C}$, and $120^{\circ} \mathrm{C}$. The temperature of $90^{\circ} \mathrm{C}$ was the optimum temperature that yielded the highest UCS. 
TABLE 2: Atterberg and SG of GMT and BOFS.

\begin{tabular}{|c|c|c|c|c|c|c|}
\hline Variable & LL (\%) & LS (\%) & PL (\%) & PI (\%) & S.G. & $\mathrm{D}_{50}(\mu \mathrm{m})$ \\
\hline GMT & 17 & 0 & 0 , nonplastic & 0, nonplastic & 2.89 & 153 \\
\hline BOFS & 13 & 0.30 & 0 , nonplastic & 0 , nonplastic & 3.56 & 43 (crushed) \\
\hline GMT: BOFS & 15 & 0.30 & 0 , nonplastic & 0 , nonplastic & 3.10 & - \\
\hline
\end{tabular}

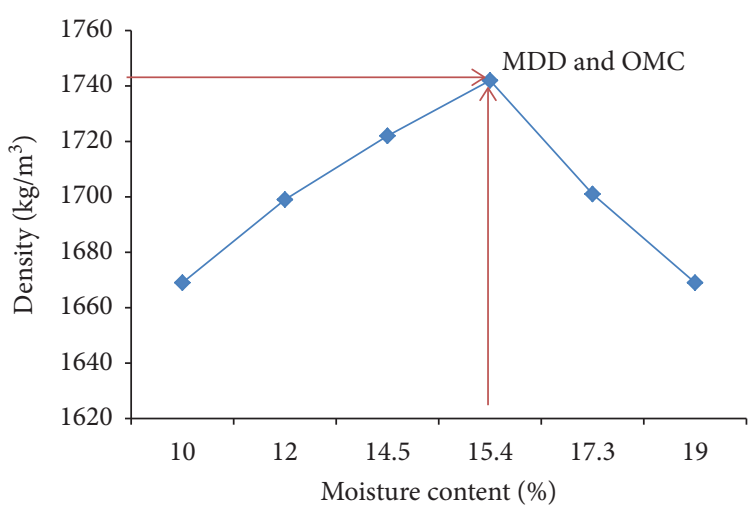

(a)

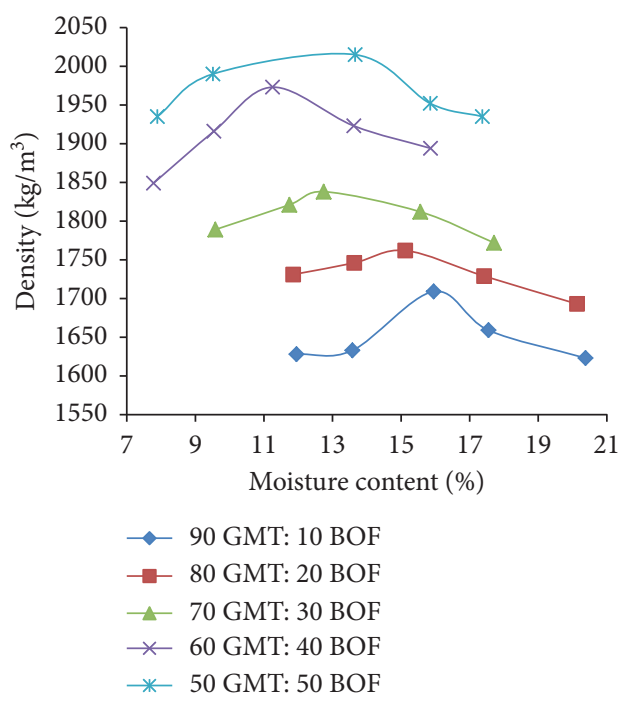

(b)

Figure 5: MDD and OMC for (a) GMT; (b) GMT: BOFS mix designs.

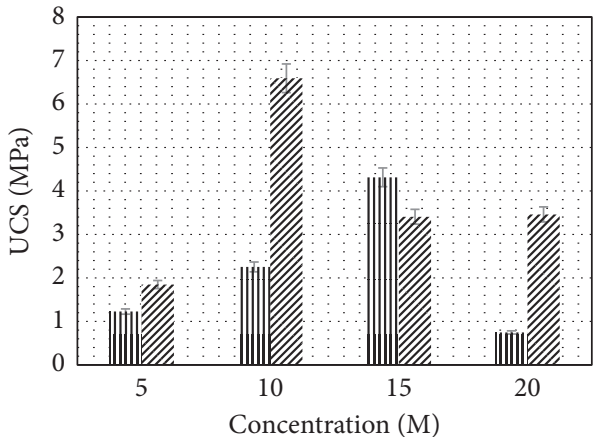

|IIIIIII $\mathrm{NaOH}$

III. $\mathrm{KOH}$

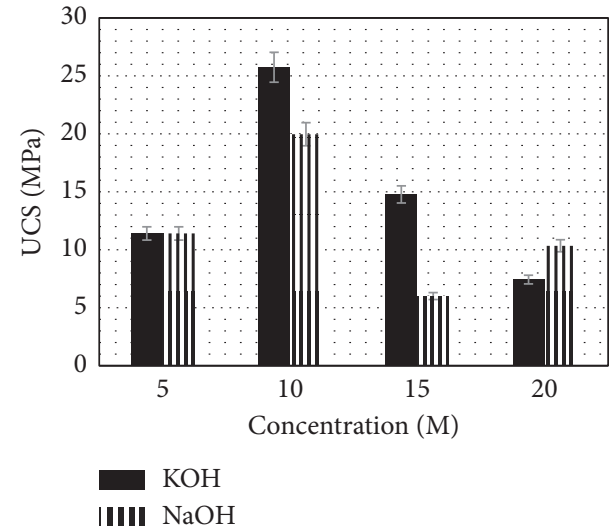

(b)

FIGURE 6: Effect of $\mathrm{KOH}$ and $\mathrm{NaOH}$ on the UCS: (a) GMT geopolymer; (b) GMT: BOFS geopolymer.

Figures 6(a) and 6(b) show the UCS of GMT geopolymer and GMT: BOFS geopolymers, respectively, with different concentrations of $\mathrm{KOH}$ and $\mathrm{NaOH}$. For GMT geopolymer, the UCS of $6.59 \mathrm{MPa}$ was achieved with $10 \mathrm{M} \mathrm{KOH}$ and $4.31 \mathrm{MPa}$ with $15 \mathrm{M} \mathrm{NaOH}$. KOH performed better than $\mathrm{NaOH}$. The UCS increased gradually and dropped when the concentrations of $\mathrm{NaOH}$ and $\mathrm{KOH}$ were increased to $20 \mathrm{MPa}$.
For the GMT: BOFS geopolymer, the UCS increased significantly to $25.7 \mathrm{MPa}$ at $10 \mathrm{M} \mathrm{KOH}$ and $19.97 \mathrm{MPa}$ at $10 \mathrm{M} \mathrm{NaOH}$. The optimum UCS was obtained at the activator's concentration of $10 \mathrm{M}$, and $\mathrm{KOH}$ also yielded the highest UCS. Falayi [48] attributed the increase in UCS with the increase in $\mathrm{KOH} / \mathrm{NaOH}$ to the availability of hydroxyl ions, which dissolved $\mathrm{SiO}_{2}, \mathrm{Al}_{2} \mathrm{O}_{3}$, and $\mathrm{CaO}$. The decrease in 


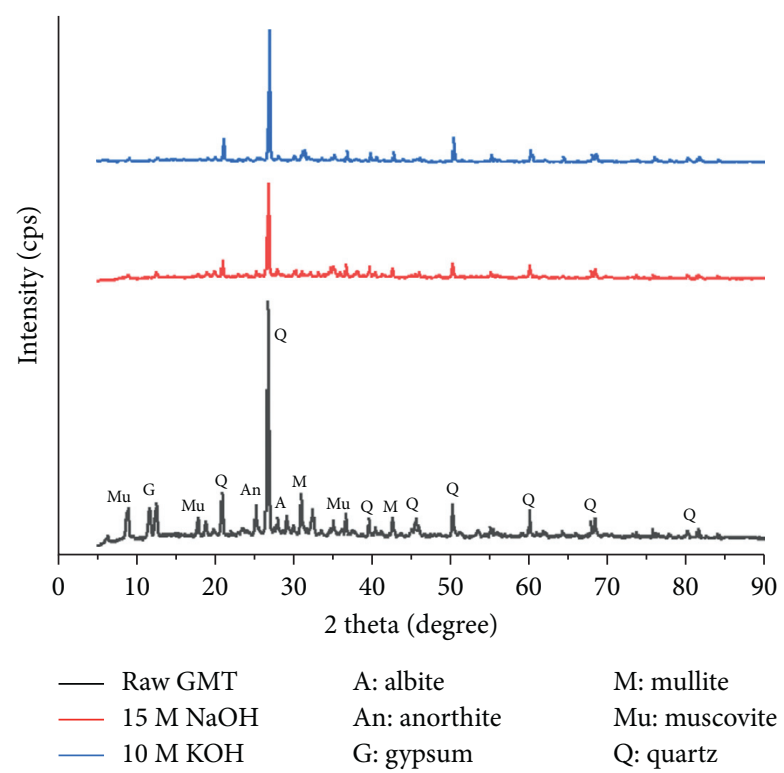

(a)

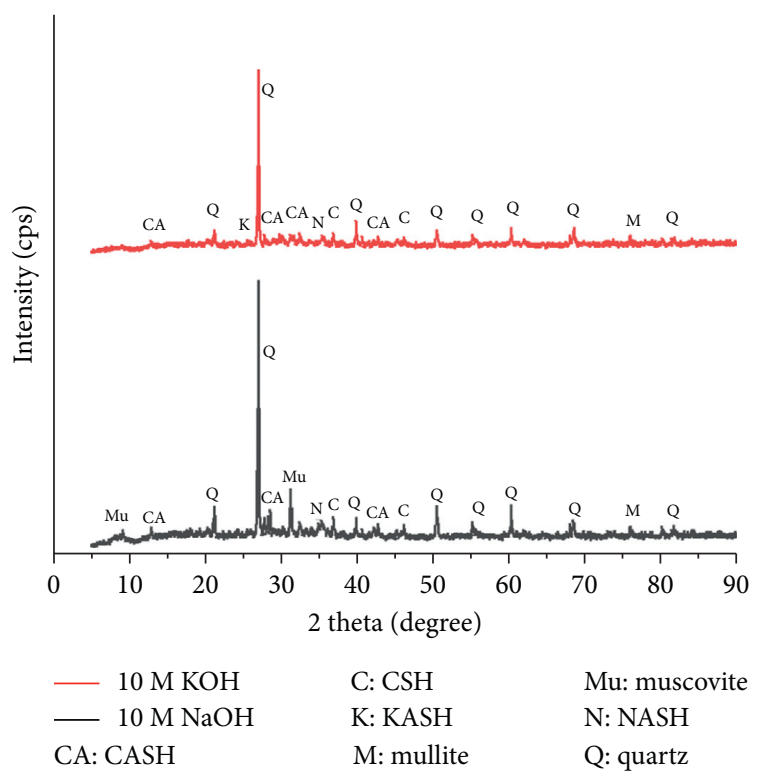

(b)

FIGURE 7: XRD of (a) GMT geopolymer at optimum conditions; (b) GMT: GBFS geopolymer at optimum conditions.

UCS after the optimum strength was attained which is attributed to free $\mathrm{Ca}^{2+}$ ions as the dissolution of $\mathrm{CaO}$ [48].

3.5.3. Mineralogy of GMT and GMT: BOFS Geopolymers at Optimum Conditions. The XRD analysis for GMT and GMT: BOFS geopolymers is presented in Figure 7.

The mineralogy of geopolymerized GMT shows a decrease in the crystalline phase when $\mathrm{NaOH}$ and $\mathrm{KOH}$ were introduced to GMT. This can be attributed to dissolution condensation polymerization that contributed to the formation of geopolymer gels [49]. Muscovite and gypsum peaks at 10-20 2 theta diminished when GMT was alkaline activated. The strength of GMT: BOFS geopolymer was greater than the UCS of GMT geopolymer, as shown in Figure 6. In the GMT: BOFS geopolymer, a new product of $\mathrm{C}-\mathrm{S}-\mathrm{H} / \mathrm{C}-\mathrm{A}-\mathrm{S}-\mathrm{H}$ gel was evident in the mineralogy of the geopolymer, and this is what has contributed to the higher UCS. There was also reduction in the crystalline phase peak when comparing geopolymers developed by $\mathrm{NaOH}$ and $\mathrm{KOH}$.

3.5.4. FTIR of GMT and GMT: BOFS Geopolymers at Optimum Conditions. The FTIR for GMT and GMT: BOFS geopolymers is presented in Figure 8.

FTIR of GMT and the geopolymer activated by $15 \mathrm{M}$ $\mathrm{NaOH}$ exhibited bends at the same wavelengths. In the geopolymer from $10 \mathrm{M} \mathrm{KOH}$, the band completely disappeared.

For GMT: BOFS geopolymer, the geopolymer with $10 \mathrm{M}$ $\mathrm{NaOH}$ showed bands similar to BOFS. Using $10 \mathrm{M} \mathrm{KOH}$ as an activator exhibited a newly formed band of geopolymer at the wavelength of about $2300 \mathrm{~cm}^{1}$. The bands at the wavelength of about $1000 \mathrm{~cm}^{-1}$ evident in both GMT and
CMT: BOFS geopolymers can be assigned to Si-O-Si bonds [49].

3.5.5. Micrography of GMT and GMT: BOFS Geopolymers at Optimum Conditions. The micrography for GMT and GMT: BOFS geopolymers is presented in Figure 4.

The micrography of GMT geopolymer activated with $\mathrm{NaOH}$ and $\mathrm{KOH}$ shows particles are loosely packed. GMT: BOFS geopolymers activated with $\mathrm{NaOH}$ and $\mathrm{KOH}$ exhibit material that is well compacted, with particles closely packed. The EDS of $\mathrm{NaOH}$-activated GMT in Figure 4(a) presents the $\mathrm{Na}-\mathrm{Si}-\mathrm{Al}$ phases in the geopolymer structure. This phenomenon was also observed and reported by Demir and Derum [19], who argued that geopolymerization reaction took place with addition of $\mathrm{Al}$ to $\mathrm{Si}$ structure in GMT, which was then activated by $\mathrm{NaOH}$ solution. A gel-like material that indicated the formation of geopolymer gel is also visible in all the geopolymers developed. There are no visible cracks on the geopolymers. Zhang et al. [50] reported that in alkaline activation of mine tailings and fly ash, as a result of activation because of the $\mathrm{NaOH}$ used, there are more geopolymers gels developed.

3.5.6. Toxicity Characteristic Leaching Procedure (TCLP) for Geopolymers. TCLP results for GMT geopolymer and GMT: BOFS geopolymers are presented in Figure 9.

The leachability of the geopolymers developed for all the optimum conditions using $\mathrm{NaOH}$ and $\mathrm{KOH}$ was studied. According to the results obtained, only traces of of iron were detected in the leachate. The concentration of Fe was within the required level, as stipulated by WHO [51]. There are no potential risks associated with the developed geopolymers. 


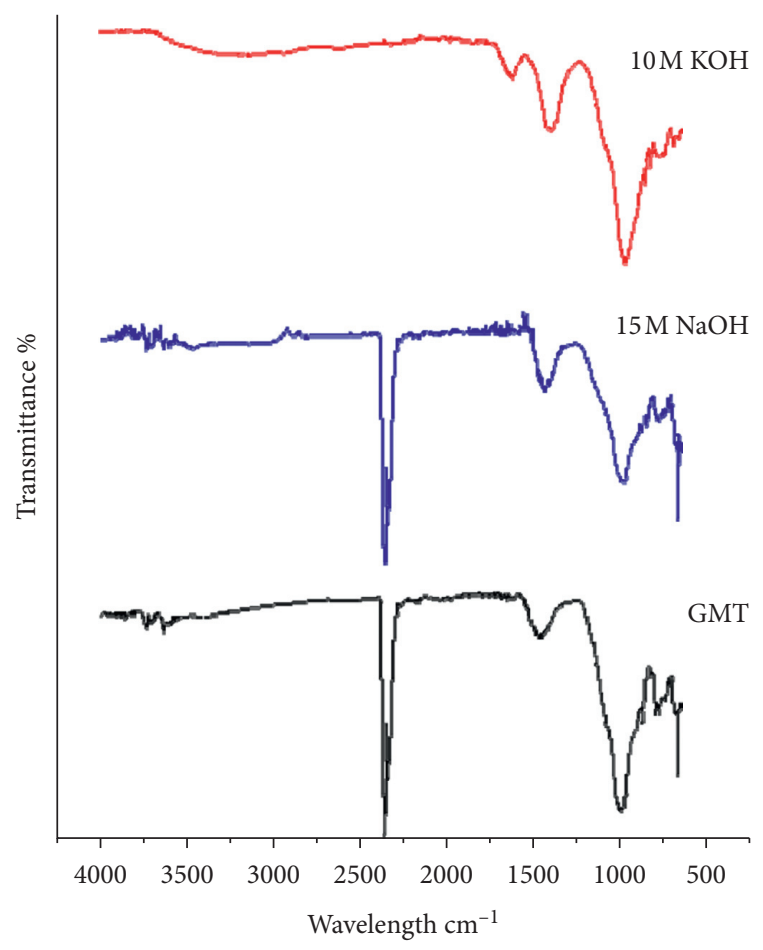

(a)

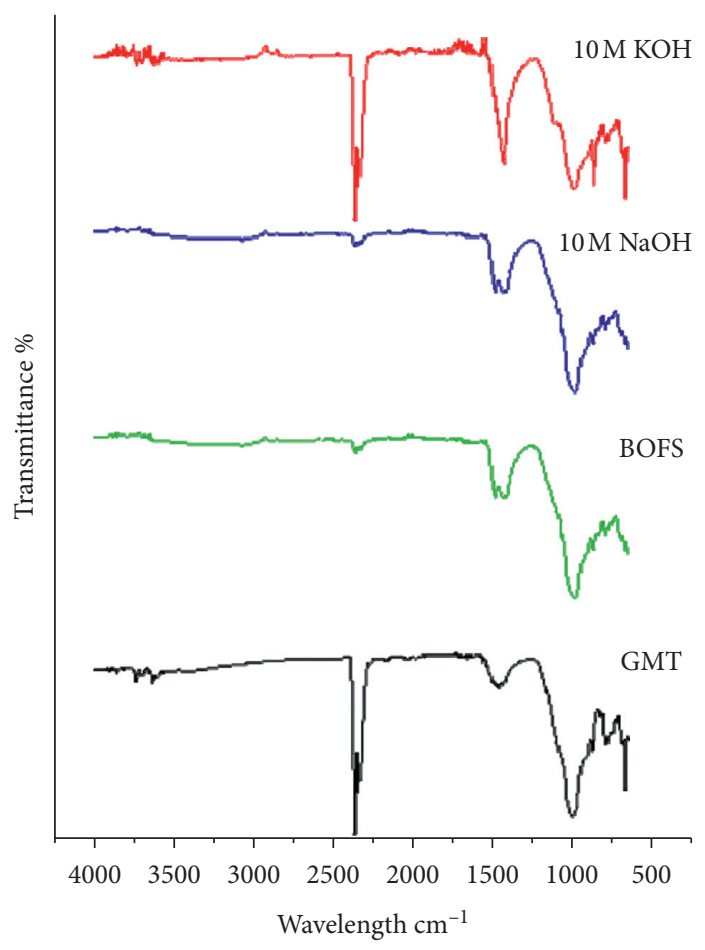

(b)

FIGURE 8: FTIR of (a) GMT geopolymer at optimum conditions; (b) GMT: GBFS geopolymer at optimum conditions.

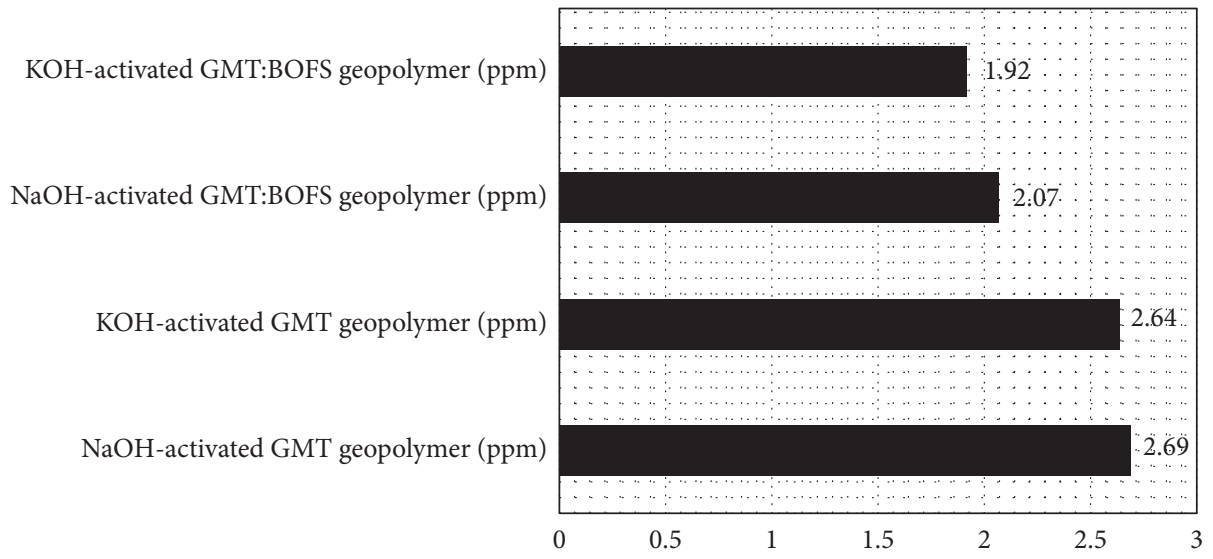

Figure 9: TCLP of the developed GMT and GMT: BOFS geopolymers.

Other metals such as copper and manganese were below the minimum detection limits. This shows that the geopolymers developed can be utilized without posing any threat to the environment.

\section{Conclusions}

The study investigated the stabilization of gold mine tailings (GMTs) by applying an alkaline activation process and studying $\mathrm{NaOH}$ and $\mathrm{KOH}$ as activators in the presence of basic oxygen furnace slag (BOFS). GMT-based and GMT: BOFS-based geopolymers were developed. GMT without stabilization yielded the highest strength of $6.59 \mathrm{MPa}$. Blending GMT and BOFS improved the UCS of the geopolymer drastically, and the highest strength of 25.71 MPa was achieved. $\mathrm{KOH}$ proved to a better activator as compared with $\mathrm{NaOH}$. The UCS attained by GMT and GMT: GBFS geopolymers met the minimum requirements for the geopolymers to be used for load-bearing applications in building and construction. The geopolymer leachability tests showed that the developed geopolymers are environmentally friendly and do not pose any potential environmental risk.

Further study should be conducted to evaluate the leaching properties by hydration thermodynamic and geochemical simulation, which can quantitatively analyze the hydration products and leaching value in different hydration periods, using the method proposed by the authors in [52]. Thus, the geopolymer leachability will be further studied 
compared with the TCLP test and simulation, to explore the leaching risk comprehensively.

\section{Data Availability}

The data used to support the findings of this study are included within the article.

\section{Disclosure}

The funders had no role in the design of the study; in the collection, analyses, or interpretation of data; in the writing of the manuscript, or in the decision to publish the results.

\section{Conflicts of Interest}

The authors declare that they have no conflicts of interest.

\section{Authors' Contributions}

T.M. and T.S. were responsible for conceptualization. T.M., J.S., and T.S. were responsible for methodology. T.M. and T.S. validated the study. T.M., J.S., and T.S. performed formal analysis. T.M. and T.S. investigated the study. T.M. provided resources. T.M., J.S., and T.S. were responsible for data curation. T.M. and T.S. were responsible for original draft preparation. T.M. and T.S. visualized the study. T.M. was responsible for funding acquisition. All authors have read and agreed to the published version of the manuscript.

\section{Acknowledgments}

The authors would like to thank the University of Johannesburg and National Research Foundation of South Africa under grant unique numbers 112237 and 121885 for the financial support.

\section{References}

[1] S. Ahmari and L. Zhang, "Durability and leaching behavior of mine tailings-based geopolymer bricks," Construction and Building Materials, vol. 44, pp. 743-750, 2013.

[2] IAEA (International Atomic Energy Agency), "The long-term stabilization of uranium mill tailings," Final Report of a Coordinated Research Project 2000-2004, IAEA-TECDOC1403, IAEA (International Atomic Energy Agency), Vienna, Austria, 2004.

[3] L. C. Lange, C. D. Hills, and A. B. Poole, "Preliminary investigation into the effects of carbonation on cement-solidified hazardous wastes," Environmental Science \& Technology, vol. 30, no. 1, pp. 25-30, 1995.

[4] E. Schoenberger, "Environmentally sustainable mining: the case of tailings storage facilities," Resources Policy, vol. 49, pp. 119-128, 2016.

[5] M. Nehdi and A. Tariq, "Stabilization of sulphidic mine tailings for prevention of metal release and acid drainage using cementitious materials: a review," Journal of Environmental Engineering and Science, vol. 6, no. 4, pp. 423-436, 2007.

[6] J. Miller, H. Akhter, F. K. Cartledge, and M. McLearn, "Treatment of arsenic-contaminated soils. II: treatability study and remediation," Journal of Environmental Engineering, vol. 126, no. 11, pp. 1004-1012, 2000.
[7] E. F. Barth, "An overview of the history, present status, and future direction of solidification/stabilization technologies for hazardous waste treatment," Journal of Hazardous Materials, vol. 24, no. 2-3, pp. 103-109, 1990.

[8] C. S. Poon and K. W. Lio, "The limitation of the toxicity characteristic leaching procedure for evaluating cement-based stabilised/solidified waste forms," Waste Management, vol. 17, no. 1, pp. 15-23, 1997.

[9] V. Dutré and C. Vandecasteele, "Immobilization mechanism of arsenic in waste solidified using cement and lime," Environmental Science \& Technology, vol. 32, no. 18, pp. 27822787, 1998.

[10] W.-H. Choi, S.-R. Lee, and J.-Y. Park, "Cement based solidification/stabilization of arsenic-contaminated mine tailings," Waste Management, vol. 29, no. 5, pp. 1766-1771, 2009.

[11] T. S. Singh and K. K. Pant, "Solidification/stabilization of arsenic containing solid wastes using portland cement, fly ash and polymeric materials," Journal of Hazardous Materials, vol. 131, no. 1-3, pp. 29-36, 2006.

[12] M. Benzaazoua, T. Belem, and B. Bussière, "Chemical factors that influence the performance of mine sulphidic paste backfill," Cement and Concrete Research, vol. 32, no. 7, pp. 1133-1144, 2002.

[13] A. Mohamed, M. Hossein, and F. Hassani, "Hydro-mechanical evaluation of stabilized mine tailings," Environmental Geology, vol. 41, no. 7, pp. 749-759, 2002.

[14] A. Saedi, A. Jamshidi-Zanjani, and A. K. Darban, "A review on different methods of activating tailings to improve their cementitious property as cemented paste and reusability," Journal of Environmental Management, vol. 270, Article ID 110881, 2020.

[15] E. Yilmaz, T. Belem, and M. Benzaazoua, "Study of physicochemical and mechanical characteristics of consolidated and unconsolidated cemented paste backfills," Mineral Resources Management, vol. 29, no. 1, pp. 81-100, 2013.

[16] F. Beya, M. Mbonimpa, T. Belem et al., "Mine backfilling in the permafrost, Part I: numerical prediction of thermal curing conditions within the cemented paste backfill matrix," Minerals, vol. 9, no. 3, p. 165, 2019.

[17] J. S. Van Deventer, J. Provis, P. Duxson, and G. C. Lukey, "Technological environmental and commercial drivers for the use of geopolymers in a sustainable material industry," in Proceedings of the Intenatinal Symposium of Advanced Processing of Metals and Materials, pp. 241-252, San Diego, CA, USA, August 2006.

[18] H. T. Kouamo, A. Elimbi, J. A. Mbey, C. N. Sabouang, and D. Njopwouo, "The effect of adding alumina-oxide to metakaolin and volcanic ash on geopolymer products: a comparative study," Construction and Building Materials, vol. 35, pp. 960-969, 2012.

[19] F. Demir and E. M. Derun, "Modelling and optimization of gold mine tailings based geopolymer by using response surface method and its application in $\mathrm{Pb}^{2+}$ removal," Journal of Cleaner Production, vol. 237, Article ID 117766, 2019.

[20] J. Kiventerä, L. Golek, J. Yliniemi, V. Ferreira, J. Deja, and M. Illikainen, "Utilization of sulphidic tailings from gold mine as a raw material in geopolymerization," International Journal of Mineral Processing, vol. 149, pp. 104-110, 2016.

[21] J. P. J. Aseniero, E. M. Opiso, M. H. T. Banda, and C. B. Tabelin, "Potential utilization of artisanal gold-mine tailings as geopolymeric source material: preliminary investigation," SN Applied Sciences, vol. 1, no. 1, p. 35, 2019. 
[22] J. Liu and D. Wang, "Influence of steel slag-silica fume composite mineral admixture on the properties of concrete," Powder Technology, vol. 320, pp. 230-238, 2017.

[23] C. Kambole, P. Paige-Green, W. K. Kupolati, J. M. Ndambuki, and A. Adeboje, "Comparison of technical and short-term environmental characteristics of weathered and fresh blast furnace slag aggregates for road base applications in South Africa," Case Studies in Construction Materials, vol. 11, Article ID e00239, 2019.

[24] Y. Feng, Q. Chen, Y. Zhou et al., "Modification of glass structure via $\mathrm{CaO}$ addition in granulated copper slag to enhance its pozzolanic activity," Construction and Building Materials, vol. 240, Article ID 117970, 2020.

[25] Y. He, Q. Zhang, Q. Chen et al., "Mechanical and environmental characteristics of cemented paste backfill containing lithium slag-blended binder," Construction and Building Materials, vol. 271, Article ID 121567, 2021.

[26] N. T. Sithole and T. Mashifana, "Geosynthesis of building and construction materials through alkaline activation of granulated blast furnace slag," Construction and Building Materials, vol. 264, Article ID 120712, 2020.

[27] J. Wu, J. Li, F. Rao, and W. Yin, "Mechanical property and structural evolution of alkali-activated slag-phosphate mine tailings mortars," Chemosphere, vol. 251, Article ID 126367, 2020.

[28] M. Dineshkumar and C. Umarani, "Effect of alkali activator on the standard consistency and setting times of fly ash and GGBS-based sustainable geopolymer pastes," Advances in Civil Engineering, vol. 2020, Article ID 2593207, 10 pages, 2020.

[29] Z. Jiao, Y. Wang, W. Zheng, and W. Huang, "Effect of dosage of alkaline activator on the properties of alkali-activated slag pastes," Advances in Materials Science and Engineering, vol. 2018, Article ID 8407380, 12 pages, 2018.

[30] G. Yao, Q. Liu, J. Wang, P. Wu, and X. Lyu, "Effect of mechanical grinding on pozzolanic activity and hydration properties of siliceous gold ore tailings," Journal of Cleaner Production, vol. 217, pp. 12-21, 2019.

[31] Q. Liu, X. Li, M. Cui, J. Wang, and X. Lyu, "Preparation of eco-friendly one-part geopolymers from gold mine tailings by alkaline hydrothermal activation," Journal of Cleaner Production, vol. 298, Article ID 126806, 2021.

[32] J. Kiventerä, H. Sreenivasan, C. Cheeseman, P. Kinnunen, and M. Illikainen, "Immobilization of sulfates and heavy metals in gold mine tailings by sodium silicate and hydrated lime," Journal of Environmental Chemical Engineering, vol. 6, no. 5, pp. 6530-6536, 2018.

[33] E. Caballero, W. Sánchez, and C. A. Ríos, "Synthesis of geopolymers from alkaline activation of gold mining wastes," Ingeniería y Competitividad, vol. 16, no. 1, pp. 317-330, 2014.

[34] T. Luukkonen, Z. Abdollahnejad, J. Yliniemi, P. Kinnunen, and M. Illikainen, "Comparison of alkali and silica sources in one-part alkali-activated blast furnace slag mortar," Journal of Cleaner Production, vol. 187, pp. 171-179, 2018.

[35] N. B. Singh and B. Middendorf, "Geopolymers as an alternative to Portland cement: an overview," Construction and Building Materials, vol. 237, Article ID 117455, 2020.

[36] S. Wang, X.-P. Song, X.-J. Wang, Q.-S. Chen, J.-C. Qin, and Y.-X. Ke, "Influence of coarse tailings on flocculation settlement," International Journal of Minerals, Metallurgy and Materials, vol. 27, no. 8, pp. 1065-1074, 2020.

[37] K. Anastasiadou, K. Christopoulos, E. Mousios, and E. Gidarakos, "Solidification/stabilization of fly and bottom ash from medical waste incineration facility," Journal of Hazardous Materials, vol. 207-208, pp. 165-170, 2012.

[38] T. Mashifana, F. Ntuli, and F. Okonta, "Leaching kinetics on the removal of phosphorus from waste phosphogypsum by application of shrinking core model," South African Journal of Chemical Engineering, vol. 27, pp. 1-6, 2019.

[39] N. T. Sithole, F. Ntuli, and F. Okonta, "Fixed bed column studies for decontamination of acidic mineral effluent using porous fly ash-basic oxygen furnace slag based geopolymers," Minerals Engineering, vol. 154, Article ID 106397, 2020.

[40] E. Belhadj, C. Diliberto, and A. Lecomte, "Characterization and activation of basic oxygen furnace slag," Cement and Concrete Composites, vol. 34, no. 1, pp. 34-40, 2012.

[41] C. Shi, "Characteristics and cementitious properties of ladle slag fines from steel production," Cement and Concrete Research, vol. 32, no. 3, pp. 459-462, 2002.

[42] A. Rađenović, J. Malina, and T. Sofilić, "Characterization of ladle furnace slag from carbon steel production as a potential adsorbent," Advances in Materials Science and Engineering, vol. 2013, Article ID 198240, 6 pages, 2013.

[43] D.-H. Shen, C.-M. Wu, and J.-C. Du, "Laboratory investigation of basic oxygen furnace slag for substitution of aggregate in porous asphalt mixture," Construction and Building Materials, vol. 23, no. 1, pp. 453-461, 2009.

[44] I. Blanco, P. Molle, L. E. Sáenz de Miera, and G. Ansola, "Basic oxygen furnace steel slag aggregates for phosphorus treatment. Evaluation of its potential use as a substrate in constructed wetlands," Water Research, vol. 89, pp. 355-365, 2016.

[45] I. Z. Yildirim and M. Prezzi, Use of Steel Slag in Subgrade Applications, Purdue University Press, West Lafayette, IN, USA, 2009.

[46] S. I. Ahmed and S. Siddiqua, "A review on consolidation behavior of tailings," International Journal of Geotechnical Engineering, vol. 8, no. 1, pp. 102-111, 2014.

[47] W.-T. Kuo, Y.-S. Gao, and C.-U. Juang, "Influence of BOF and GGBFS based alkali activated materials on the properties of porous concrete," Materials, vol. 12, no. 14, p. 2214, 2019.

[48] T. Falayi, "A comparison between fly ash-and basic oxygen furnace slag-modified gold mine tailings geopolymers," International Journal of Energy and Environmental Engineering, vol. 11, pp. 207-217, 2020.

[49] R. J. Bell and P. Dean, "Atomic vibrations in vitreous silica," Discussions of the Faraday Society, vol. 50, pp. 55-61, 1970.

[50] L. Zhang, S. Ahmari, and J. Zhang, "Synthesis and characterization of fly ash modified mine tailings-based geopolymers," Construction and Building Materials, vol. 25, no. 9, pp. 3773-3781, 2011.

[51] World Health Organization, Safety Evaluation of Certain Food Additives and Contaminants, Vol. 68, World Health Organization, Geneva, Switzerland, 2008.

[52] Q. S. Chen, S. Y. Sun, Y. K. Liu, C. C. Qi, H. B. Zhou, and Q. L. Zhang, "Experimental and numerical study on immobilization and leaching characteristics of fluoride from phosphogypsum based cemented paste backfill," International Journal of Minerals, Metallurgy and Materials, 2021. 